\title{
Memahami Komunikasi Pemasaran Politik
}

\author{
Ibnu Hamad
}

ABSTRACT

\begin{abstract}
This article explores political marketing communication as a means of political communication using concept and marketing communication techniques to buy political product. According to the goals (such as position, title, and wealth), what considered as political communication products in its broadest terms are leadership, institution, membership, policy, and political activities. Principles, methods, and stages of political communication must be attended seriously so that the product being sold would be embraced by political audience.
\end{abstract}

Kata kunci: komunikasi pemasaran, komunikasi politik, produk politik

\section{Komunikasi Pemasaran Politik: Menjual Produk Politik}

Pengertian yang umum tentang komunikasi pemasaran adalah (sejumlah) kegiatan komunikasi -sering disebut promosi- dalam rangka penjualan produk berupa barang atau jasa. Produsen sandang, pangan, dan papan melakukan promosi untuk menjual barang berupa pakaian, makananminuman, dan perumahan. Pengusaha perbankan, asuransi, angkutan, berpromosi untuk menjual jasanya kepada konsumen. Umumnya, para profesional dan buruh mempromosikan jasa mereka kepada para pihak yang bersedia membayar atau menggajinya.

Komunikasi pemasaran politik berarti kegiatan promosi guna menjual produk politik (political product). Di sini, ada dua pertanyaan: apakah produk politik itu? Dan seperti apakah kegiatan komunikasi pemasaran (promosi) produk politik tersebut? Sederhananya, produk politik adalah janji-janji politik dari aktor atau lembaga (partai) politik. Untuk kandidat, seorang aktor politik cenderung banyak membuat janji politik sebagai produk politiknya; sementara jika telah menjadi pejabat politik, si aktor menjanjikan berbagai program pembangunan sebagai produk politiknya.

Untuk partai politik, Lees-Marshment (Lilleker dan Lees-Marshment, 2005:5-6) menunjukkan daftar produk partai sebagaimana tampak dalam box 1 dengan penyederhanaan seperlunya.

Tentu saja, produk politik itu bisa berubahubah sesuai situasi dan kondisi sistem politik yang berlaku. Dalam sistem demokratis multipartai, produk politik yang ditawarkan lebih beragam ketimbang dalam sistem demokratis yang dwipartai demi menarik perhatian konstituen. Dalam sistem otoriter, produk politik biasanya seragam dan monolitik.

Produk politik juga bisa berbeda berdasarkan cakupan wilayah nasional ataukah kedaerahan. Janji politik capres tentu saja berbeda dari calon gubernur, bupati, atau walikota. Produk pilitik satu negara/daerah dapat berbeda dari negara/daerah. Perbedaan produk politik juga sudah dipastikan berdasarkan orientasi ideologis masing-masing 


\section{Box 1: Daftar Produk Partai}

- Kepemimpinan (leadership): kekuasaan, citra, karakter, dukungan, pendekatan, hubungan dengan anggota partai, hubungan dengan media

- Anggota parlemen (members of parliement): sifat kandidat, hubungan dengan konstituen

- Keanggotaan (membership): kekuasaan, rekrutmen, sifat (karakter ideologi, kegiatan, loyalitas, tingkah laku, hubungan dengan pemimpin.

- Staf (staff): peneliti, profesional, penasihan

- Simbol (symbol): nama, logo, lagu/himne

- Konstitusi (constituion): aturan resmi dan formal

- Kegiatan (activities): konfrensi, rapat partai

- Kebijakan (policies): menifesto dan aturan yang berlaku dalam partai

Sumber: Lees-Marshment (Lilleker dan Lees-Marshment, 2005:5-6)

partai atau aktor politik. Partai berasas agama akan memiliki produk politik yang berbeda dari partai sekuler atau partai kiri. Produk politik partai hijau (green party) adalah janji menyelamatkan lingkungan hidup; sedangkan produk partai perempuan adalah janji membangun kesetaraan jender.

Adapun tentang kegiatan komunikasi pemasaran (promosi) produk politik, sebagaimana akan diuraikan nanti, secara umum dikenal dalam bentuk periklanan politik (political advertising). Tapi, sebetulnya komunikasi pemasaran politik bisa dalam bentuk bauran pemasaran politik (promotion mix of politic); bahkan dalam bentuk komunikasi pemasaran politik terpadu (integrated marketing communication of politic). Namun, sebelum membahas masalah ini, ada baiknya kita ketahui latar lahirnya komunikasi pemasaran politik.

\section{Latar Belakang Lahirnya Komunikasi Pemasaran Politik}

Sebagai wujud dari upaya mencapai tujuantujuan politik, hingga dekade 80-an, komunikasi politik acapkali dipertukarkan dengan propaganda politik dan disamakan dengan usaha menciptakan pendapat umum. Dalam bentuk yang sempit, kegiatan kampanye menjelang pemilu sering dianggap sebagai komunikasi politik.

Memasuki dekade 90-an, pemasaran politik mulai banyak dibahas, bahkan dipraktikkan. Pemasaran politik tampaknya lahir dari kebutuhan bahwa untuk menjual produk politik tidak bisa dilakukan hanya dalam suatu waktu tertentu, melainkan harus dalam jangka yang panjang. Hal ini tampaknya disebabkan oleh dua faktor yang saling berkaitan.

Faktor pertama, adalah semakin kuatnya demokrasi tak terkecuali di Indonesia. Pengadopsian sistem demokrasi, terlebih dengan sistem multipartai menyebabkan para pelaku harus bersaing ketat memperebutkan dukungan publik, Sehingga kegiatan komunikasi politik pun tak hanya dibatasi pada saat kampanye, melainkan sepanjang waktu layaknya para produsen barang dan jasa memasarkan produknya sepanjang tahun.

Faktor kedua, adalah praktik eknomi pasar bebas (free market economy) yang makin meluas di muka bumi dan memberi pengaruh juga dalam praktik berdemokrasi termasuk di Indonesia. Seperti kita tahu, dalam ekonomi pasar bebas, keputusan pembelian ditentukan oleh mekanisme pasar. Harga adalah hasil kompromi antara penawaran dan permintaan. Pembeli bebas memilih 
apapun yang diminatinya, sementara penjual hanya berusaha meyakinkan konsumen melalui berbagai kegiatan promosi melalui ragam media tanpa ada unsur pemaksaan.

Demikian pula, perilaku politik dewasa ini berada dalam demokrasi ala free market economy sangat bebas (Lange dalam Lange dan Ward, 2004 : 207). Khalayak bebas menentukan sikap politik mereka sesuai kehendak hatinya. Mereka bebas berpindah dalam memberi dukungan kepada aktor politik dari waktu ke waktu. Dalam situasi demikian, hanya lembaga, pejabat, dan kandidat politik yang dikenal oleh khalayak politik yang akan mendapat dukungan suara atau opini publik.

Di tengah praktik pasar politik yang bebas, bukan jamannya aktor politik memaksa, apalagi mengancam untuk mencari dukungan; melainkan harus beralih kedalam usaha mempromosikan diri dengan pendekatan komunikasi pemasaran yang canggih melalui bermacam saluran komunikasi politik. Jika mereka berhasil meyakinkan publik, niscaya akan mendapat dukungan politik.

Dalam sistem ekonomi pasar bebas, para penjual sekuat tenaga mempersuasi para (calon) pelanggan. Begitu pula dalam kegiatan politik. Mereka gunakan beragam media yang secara umum terbagi atas enam kelompok. Pertama, saluran komunikasi politik lini atas (above the line/ATL) dalam bentuk koran, majalah, radio dan TV. Kedua, saluran komunikasi politik lini bawah (below the line/BTL) berupa poster, spanduk, leaflet, sticker. Ketiga, saluran komunikasi politik melalui special event dalam bentuk kegiatan-kegiatan yang dirancang khusus untuk tujuan politik, seperti peringatan HUT parpol, acara peluncuran buku yang ditulis seorang tokoh politik, kegiatan konvensi parpol, dan sejenisnya. Keempat, saluran komunikasi politik melalui media baru (newmedia) dalam bentuk peluncuran website parpol dan tokoh politik. Kelima, saluran komunikasi politik dengan komunikasi antar pribadi (interpersonal communication) baik secara langsung dari seorang politikus kepada politikus lainnya maupun secara tidak langsung melalui mediator atau penghubung. Keenam, saluran komunikasi politik dengan media tradisional yang basisnya adalah seni pertunjukkan rakyat (falk art) seperti wayang (Jawa), mamanda (Kalimantan), bangsawan (Riau), dan sebagainya.

Begitu pesatnya kemajuan media serta penggunaannya yang amat luas dalam kancah politik, sehingga McNair (2003 : 1-91). menyebut politik di zaman sekarang dengan politik di era mediasi (politics in the age of mediation).

Faktanya, akhir-akhir ini aktivitas politik, tak terkecuali di Indonesia, banyak menggunakan media untuk menjangkau target khalayak politiknya. Pemakaian media, temasuk media baru, (Axford dan Huggins, 2001) adalah untuk mencapai tujuan politik mereka dan untuk mengatasi hambatan-hambatan komunikasi dengan target khalayak politiknya, baik secara geografis, demografis, maupun psikografis, mengingat besar jumlahnya dan luasnya sebaran khalayak politik itu. Mereka memakai media bukan hanya ketika kampanye, tetapi sepanjang waktu dan kesempatan.

Yang sangat menggembirakan adalah, ternyata penggunaan media politik ini dilakukan atas dasar perencanaan media (media planning) tertentu. Seperti halnya dalam pemasaran, pemakaian media dalam pemasaran politik ditujukan untuk menjangkau (to reach) dan mencakup (to coverage) khalayak sasaran politik. Menjangkau di sini mengacu kepada jumlah (persentase) dari sasaran khalayak politik yang terkena/terpapar pesan sedikitnya satu sekali oleh pesan politik. Jika pesan mengenai $80 \%$ khalayak sasaran, maka hal itu menunjukkan bahwa jangkauan pesan adalah 80 . Adapun arti mencakup lebih luas dari jangkauan. Cakupan merujuk pada jumlah khalayak sasaran yang potensial terpapar oleh pesan. Cakupan selalu lebih besar dari jangkauan. Ia merupakan jumlah keseluruhan (populasi) dari khalayak sasaran yang mungkin bisa dijangkau (Fill, 1999: 329).

\section{Komunikasi Pemasaran Politik: Pengayaan Komunikasi Politik dengan Komunikasi Pemasaran}

Seperti halnya dalam kegiatan pemasaran lainnya, dalam pemasaran politik ada "penjual" dan 
"pembeli" disamping produk politik. Dalam konteks ini, penjual di sini adalah para komunikator politik sedangkan si pembeli ialah khalayak politik atau dikenal pula dengan konstituen.

Untuk menjual suatu produk, kegiatan pemasaran memakai sejumlah metode komunikasi pemasaran. Untuk menjual produk-produk politik, para pelaku politik memerlukan teknik-teknik komunikasi pemasaran politik. Tujuan dari kegiatan pemasaran adalah agar konsumen bersedia mengeluarkan biaya dan atau tenaga atas produk atau jasa yang ditawarkan. Sedangkan tujuan dari pemasaran politik adalah supaya khalayak politik (konstituen) mendukung atau memberikan suara kepada aktor atau lembaga/partai yang memberi mereka janji-janji politik.

Hingga era 80-an, upaya mencapai tujuantujuan politik - mendapatkan kekuasaan, pengaruh, jabatan, kedudukan, kekayaan, dan sebagainya - dilakukan melalui komunikasi politik. Sebagai alat, komunikasi politik bekerja dalam sebuah proses yang memadukan antara komunikator politik, pesan politik, saluran komunikasi politik, dan khalayak politik untuk menghasilkan efek komunikasi politik (baca, tujuan politik).

Komunikator politik, dalam komunikasi politik, dibedakan kedalam tiga jenis: (1) aktivis sebagai komunikator politik, yang menyuarakan kepentingan kelompok dengan idealisme tertentu, biasanya dalam rangka perubahan politik; (2) profesional sebagai komunikator politik, yaitu mereka yang bekerja dan dibayar untuk kepentingan politik tertentu dari partai, kandidat, atau pejabat politik; dan (3) pejabat sebagai komunikator politik, yaitu mereka yang bercita-cita menduduki atau mempertahankan posisi tertentu dalam suatu jaringan kekuasaan (Nimmo, 1978 : 24-30).

Pesan politik dalam komunikasi politik dilakukan melalui penggunaan simbol-simbol politik atau political symbols (Nimmo, 1978 : 6293). Wujudnya adalah dalam bentuk pembicaraan politik (politics as talk) yang dibedakan ke dalam: pembicaraan kekuasaan (power talk), pembicaraan kewenangan (authority talks), pembicaraan pengaruh (influence talks). Jika pembicaraan kekuasaan dilakukan dengan cara mengancam atau janji, maka pembicaraan kewenangan bersifat memberi perintah dan larangan. Sedangkan pembicaraan pengaruh itu memberi nasihat, dorongan, permintaan, dan peringatan. Untuk memastikan pesan-pesan ini sampai ke khalayak politik, dipakailah berbagai saluran komunikasi politik, baik media lini atas (above the line/ATL), media lini bawah (below the line/BTL), special event, saluran komunikasi antar pribadi (interpersonal communication), maupun media tradisional.

Lantas, siapakah khalayak politik itu? Adalah perorangan, kelompok, atau organisasi yang menjadi sasaran komunikasi politik. Disadari bahwa khalayak politik itu memiliki kepercayaan dan sikap politik tertentu, sehingga bukan perkara mudah membentuk pendapat umum (public opinion) di tengah suatu khalayak politik.

Adapun efek komunikasi politik secara umum adalah timbulnya opini publik yang diorientasikan pada munculnya dukungan dan partisipasi politik. Dalam konteks pemilu, pilpres, pilkada, bentuk partisipasi politik ini yang paling diharapkan adalah pemberian suara untuk partai atau kandidat politik. Selanjutnya, dari partisipasi politik itu para aktor politik selaku politik menginginkan diperolehnya kekuasaan, jabatan, atau keuntungan material.

Secara lebih khusus, efek sebuah komunikasi politik sangat tergantung pada tujuan dan cara masing-masing komunikator politik memanfaatkan proses komunikasi politik. Bagi aktivis politik, efek komunikasi politik yang diinginkan adalah perubahan politik. Bagi profesional politik, efek komunikasi politik yang hendak dicapai adalah sesuai keinginan aktor politik yang dibela sang profesional. Sedangkan bagi pejabat politik, efek komunikasi politik yang ingin diciptakan lazimnya adalah pencapaian posisi tertentu dalam jaringan politik.

Mulai awal 90-an, dalam rangka mencapai efek komunikasi politik (tujuan-tujuan politik) komunikator politik menggunakan prinsip-prinsip dan metode komunikasi pemasaran untuk menjual produk-produk politik. Seperti kita tahu, prinsipnya komunikasi pemasaran adalah pemanfaatan unsur- 
unsur komunikasi-komunikator, pesan, saluran, khalayak, dan hal-hal lain yang terkait — seraya mempertimbangkan jenis produk dan target khalayak untuk kepentingan penjualan barang atau jasa. Dengan demikian, komunikasi yang dilakukan sangat memperhitungkan STP (segmenting, targeting, positioning) dari produk yang hendak dipasarkan. Segmenting adalah penentuan kelompok masyarakat yang potensial untuk membeli produk baik atas dasar geografis, demografis, psikografis, atau yang lainnya. Targeting ialah penetapan individu atau kelompok khalayak yang akan menjadi sasaran penjualan produk. Sedangkan positioning adalah pengembangan karakteristik tertentu dari produk yang hendak dipasarkan.

Untuk memperkuat komunikasi pemasaran, dilakukan pula usaha menyelami prilaku (calon) konsumen (consumer behavior). Lazimnya prilaku konsumen meliputi persepsi, pembelajaran, dan ingatan (learning and memory), sikap, motivasi dan emosi, kepribadian, gaya hidup, dan konsep diri, serta cara konsumen mengambilan keputusan dalam membeli sebuah produk (Sutisna, 2002).

Adapun teknik komunikasi pemasaran yang secara tradisional dilakukan adalah promosi. Promosi sendiri adalah salah satu komponen dalam bauran pemasaran (marketing mix) 4P (product, price, place, and promotion). Belakangan bukan hanya promosi parsial yang dilakukan, melainkan dipakai teknik bauran promosi (promotion mix) yang terdiri dari periklanan (adverstising), promosi penjualan (sales promotion), penjualan pribadi (personal selling), pemasaran langsung (direct marketing), dan public relation/publicity. Bahkan dewasa ini berkembang metode yang lebih canggih lagi, yaitu komunikasi pemasaran terpadu (integrated marketing communication/IMC) sebagaimana akan dibahas lebih lanjut.

Walhasil, sebagai akibat penggunaan prinsipprinsip dan metode komunikasi pemasaran ini maka komunikasi politik mendapat pengayaan dan melahirkan teori dan praktik komunikasi pemasaran politik. (Lilleker dan Lees-Mashment, 2005 : 6; O'Shaughnessy dan Hanneberg, 2002; Newman, 1999). Untuk menjamin bahwa produk politik itu
Box 2: Logika Matematis Pemasaran Politik

Komunikasi politik

Komunikasi pemasaran

Komunikasi pemasaran politik

diminati oleh khalayak politik, dilakukanlah pengenalan atas perilaku khalayak politik (political behavior) yang sejajar dengan consumer behavior dalam komunikasi pemasaran, pengembangan desain produk politik (design of political product) atau strategi STP dalam komunikasi pemasaran; dan penggunaan berbagai saluran komunikasi politik atau bauran promosi/ IMC dalam komunikasi pemasaran.

Jika pengayaan komunikasi politik dengan prinsip dan metode komunikasi pemasaran itu diilustrasikan secara konseptual, hasil rumusan logika matematisnya adalah sebagai tampak dalam Box 2. Bahwasanya, pemasaran politik adalah penambahan (pemanfaatan) komunikasi pemasaran untuk komunikasi politik. Kata lainnya, komunikasi politik yang memanfaatkan komunikasi pemasaran itulah yang menjadi pemasaran politik. Cakupan tujuan politikpun bertambah luas, tidak lagi sebatas untuk memperoleh kekuasaan, jabatan, kedudukan, dan sejenisnya, melainkan pula untuk menciptakan dan memelihara pangsa pasar produk politik di tengah khalayak politik.

\section{Simulasi Model Komunikasi Pemasaran untuk Politik: dari Bauran Promosi ke IMC}

Sudah dikatakan, secara tradisional promosi adalah kegiatan utama dalam komunikasi pemasaran dan lazimnya mengambil kegiatan dalam bentuk periklanan. Dalam perkembangan selanjutnya adalah bauran promosi (promotion mix) yang terdiri dari periklanan (adverstising), promosi penjualan (sales promotion), penjualan pribadi (personal selling), pemasaran langsung (direct marketing), dan pub- 
Box 3. KontinumKomunikasi Pemasaran (Komunikasi Pemasaran Terpadu)

\begin{tabular}{|cccc|}
\hline $\begin{array}{l}\text { Desain } \\
\text { Produk }\end{array}$ & Distribusi & \multicolumn{2}{c|}{$\begin{array}{c}\text { Periklanan } \\
\text { Pemasaran Langsung } \\
\text { Special Event }\end{array}$} \\
\hline Pengemasan & Harga & $\begin{array}{c}\text { Di dalam } \\
\text { Toko }\end{array}$ & $\begin{array}{r}\text { Pelayanan } \\
\text { Pelanggan }\end{array}$ \\
\hline
\end{tabular}

Sumber: Shultz, Tannenbaum \& Lauterborn (1994 : 46)

Box 4. Pendekatan Komunikasi Pemasaran Terpadu untuk Pemasaran Politik

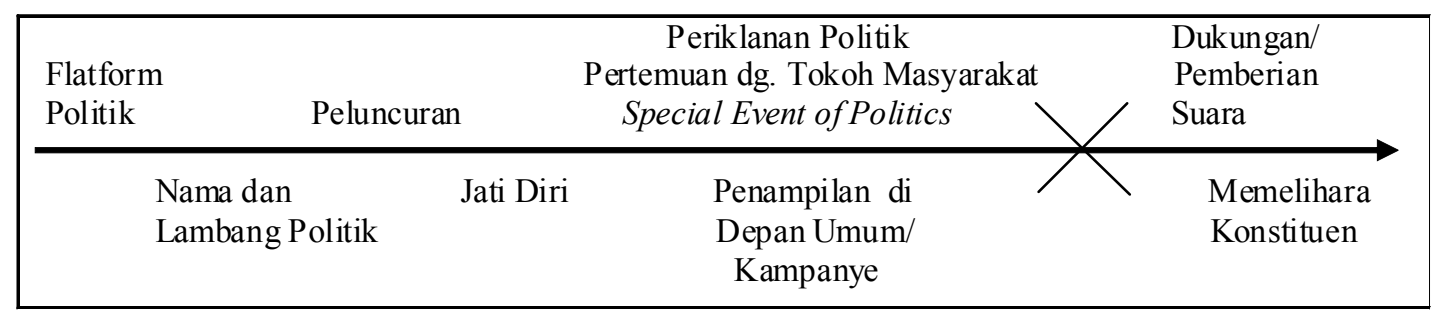

lic relation/publicity.

Jika bauran promosi ini diterapkan untuk penjualan lembaga, pejabat, atau kandidat politik, hasilnya adalah bauran promosi politik (promotion mix of politic) yang terdiri dari pemasangan iklan politik (political advertising), promosi penjualan produk politik (sales promotion of political product), pemasaran langsung produk politik (direct marketing of political product), dan kegiatan public relation/publicity politik. Dan jika dalam komunikasi pemasaran bauran promosi dipersiapkan secara matang, demikian pula dalam bauran promosi politik harus diperhitungkan dengan secermat-cermatnya.

Boleh jadi, bauran promosi politik ini tidak memadai lagi. Untuk itu, ada IMC untuk politik. Untuk IMC politik, kita dapat membuat simulasi sebagaimana terlihat dalam Box 3. Di situ, tampak bahwa menurut IMC, komunikasi pemasaran dimulai sejak dari desain produk hingga pascapembelian. Untuk membangun hubungan dengan pelanggan, komunikasi pemasaran tidak hanya berbentuk periklanan, pemasaran langsung, dan special event. Bentuk, kemasan, distribusi, dan harga produk, juga memiliki dimensi komunikasi pemasaran. Begitu pula pemajangan produk di dalam toko dan proses pembelian mesti diorientasikan sebagai komunikasi pemasaran. Bahkan, komunikasi pemasaran itu terus dilanjutkan setelah transaksi terjadi dalam bentuk pelayanan pelanggan.

Jika prinsip IMC ini kita terapkan kedalam pemasaran politik, maka yang diupayakan tentunya lebih dari sebatas agar khalayak politik mendukung atau memberikan suara saat pemilihan (Box 4). Pemasaram politik dengan IMC ditujukan untuk membangun hubungan yang baik dengan konstituen (constituent relationship), menciptakan loyalitas politik (political loyality) konstituen kepada lembaga, pejabat, dan kandidat politik, serta untuk memperkuat nilai politik (political equity) lembaga, pejabat, dan kandidat politik di tengah konstituen.

Sementara itu, bentuk-bentuk komunikasi pemasaran dalam IMC itu banyak macamnya dan semuanya dapat dipergunakan untuk pemasaran politik sebagaimana tampak dalam Tabel 1 .

Perlu ditegaskan bahwa ciri utama IMC adalah proses pengelolaan hubungan dengan pelanggan (customer relationship) di mana hubungan ini 


\section{Tabel 1: Bentuk-bentuk Komunikasi Pemasaran dan Penggunaannya untuk Pemasaran Politik}

\begin{tabular}{|c|c|c|}
\hline No. & Bentuk Komunikasi Pemasaran & Penggunaan Untuk Pemasaran Politik \\
\hline \multicolumn{3}{|c|}{ Menggunakan Media Massa } \\
\hline 1. & $\begin{array}{l}\text { Iklan di media massa. Memasang iklan di } \\
\text { media massa untuk menjual produk. }\end{array}$ & $\begin{array}{l}\text { Memasang iklan di media massa, untuk menjual produk } \\
\text { politik. }\end{array}$ \\
\hline 2. & $\begin{array}{l}\text { Public relation (PR). Mengelola citra dan } \\
\text { reputasi perusahaan di hadapan publik yang } \\
\text { terkait }\end{array}$ & $\begin{array}{l}\text { Melaksanakan fungsi PR untuk membangun hubungan } \\
\text { dengan ragam jenis khalayak, memfasilitasi publisitas dan } \\
\text { memantau opini publik mengenai produk politik }\end{array}$ \\
\hline 3. & $\begin{array}{l}\text { Marketing public relation (MPR). } \\
\text { Melakukan publisitas di media massa } \\
\text { tentang produk atau merek. }\end{array}$ & $\begin{array}{l}\text { Melaksanakan fungsi MPR untuk menjual produk politik } \\
\text { kepada konstituen. }\end{array}$ \\
\hline \multicolumn{3}{|c|}{ Memanfaatkan Situasi } \\
\hline 4. & $\begin{array}{l}\text { Promosi penjualan. Memberi insentif seperti } \\
\text { kupon. }\end{array}$ & $\begin{array}{l}\text { Membagi-bagi hadiah/bantuan/sumbangan kepada } \\
\text { khalayak politik. }\end{array}$ \\
\hline 5. & Perdagangan. Menjual produk di dalam toko. & $\begin{array}{l}\text { Menjual produk politik di kantong-kantong suara yang } \\
\text { telah teridentifikasi. }\end{array}$ \\
\hline 6. & $\begin{array}{l}\text { Display materi penjualan. Memajang materi- } \\
\text { materi yang dijual di dalam toko. }\end{array}$ & $\begin{array}{l}\text { Memajang produk-produk politik dalam bentuk } \\
\text { gambar/foto, tulisan, dan bentuk sajian lainnya }\end{array}$ \\
\hline 7. & $\begin{array}{l}\text { Pengemasan. Kemasan sebagai wadah dan } \\
\text { medium komunikasi. }\end{array}$ & $\begin{array}{l}\text { Mengemas produk politik, antara lain dengan lambang, } \\
\text { hama, lagu, dan sebagainya }\end{array}$ \\
\hline 8. & $\begin{array}{l}\text { Iklan khusus. Iklan yang berisi insentif untuk } \\
\text { para pelanggan. }\end{array}$ & $\begin{array}{l}\text { Memasang iklan khusus (spesial) di media ATL untuk } \\
\text { memotivasi para pemilih/khalayak politik }\end{array}$ \\
\hline 9. & Lisensi. Menjual hak penjualan atau paten. & $\begin{array}{l}\text { Memperluas jaringan ke berbagai lapisan sosial untuk } \\
\text { memperkenalkan produk politik }\end{array}$ \\
\hline \multicolumn{3}{|c|}{ Hubungan Personal } \\
\hline 10. & $\begin{array}{l}\text { Pemasaran langsung yang responsif. } \\
\text { Menciptakan kebutuhan dan pemenuhan } \\
\text { para pelanggan secara perorangan. }\end{array}$ & $\begin{array}{l}\text { Memasarkan produk politik secara door to door kepada } \\
\text { khalayak politik secara perorangan. }\end{array}$ \\
\hline 11. & $\begin{array}{l}\text { e-commerce. Melakukan penjualan langsung } \\
\text { kepada pelanggan melalui internet. }\end{array}$ & $\begin{array}{l}\text { Membuat web-site yang berisikan segala hal yang } \\
\text { berkaitan dengan produk politik kepada khalayak. }\end{array}$ \\
\hline 12. & $\begin{array}{l}\text { Perjualan pribadi. Komunikasi langsung } \\
\text { antara penjual dan calon pembeli. }\end{array}$ & $\begin{array}{l}\text { Melakukan komunikasi pemasaran politik secara secara } \\
\text { langsung kepada teman/orang lain }\end{array}$ \\
\hline 13. & $\begin{array}{l}\text { Pemasaran internal. Menjual produk kepada } \\
\text { karyawan demi kesuksesan program. }\end{array}$ & $\begin{array}{l}\text { Memberitahu dan memotivasi para anggota partai, tim } \\
\text { sukses dan orang-orang terdekat dengan produk politik. }\end{array}$ \\
\hline \multicolumn{3}{|c|}{ Melalui Pengalaman } \\
\hline 14. & $\begin{array}{l}\text { Events dan sponsorship. Melaksanakan suatu } \\
\text { kegiatan dengan dukungan sponsor guna } \\
\text { membangun hubungan asosiatif antara } \\
\text { merek dan publik }\end{array}$ & $\begin{array}{l}\text { Melaksanakan suatu kegiatan politik, misalnya seminar, } \\
\text { yang didukung oleh ormas atau lembaga tertentu sehingga } \\
\text { mengesankan banyaknya dukungan . }\end{array}$ \\
\hline 15. & $\begin{array}{l}\text { Pameran dagang. Mengikuti pameran dagang } \\
\text { dengan mendisplay/memajang produk- } \\
\text { produk dan menyediakan informasi kepada } \\
\text { pembeli potensial. }\end{array}$ & $\begin{array}{l}\text { Menyediakan informasi, mendemonstrasikan dan } \\
\text { menunjukkan keunggulan produk politik membuka dialog } \\
\text { langsung dengan khalayak politik. }\end{array}$ \\
\hline 16. & $\begin{array}{l}\text { Pelayanan konsumen. Menjelaskan } \\
\text { hubungan produk dengan kehidupan } \\
\text { konsumen setelah mereka membeli produk } \\
\text { tsb. }\end{array}$ & $\begin{array}{l}\text { Menjaga hubungan dan perasaan positif dengan khalayak } \\
\text { politik (pemilih) yang telah memberi dukungan politik } \\
\text { atau memberikan suara dalam pemilihan. }\end{array}$ \\
\hline
\end{tabular}

Sumber: Tom Duncan (2002:20-21) dengan pengolahan seperlunya. 
bersifat menggerakkan nilai merek. IMC adalah proses yang lintas-fungsi guna menciptakan dan memperbaiki hubungan yang menguntungkan dengan para pelanggan dan stakeholder lainnya melalui pengendalian secara strategis seluruh pesan yang dikirimkan dan memperkuatnya dengan data yang berguna bagi mereka.

Dengan demikian, hal yang mendasar dalam IMC adalah hubungan dengan pelanggan (customer relationship) bukan pemasaran (marketing) itu sendiri. Metode utama untuk membangun hubungan dengan pelanggan ini ialah dengan menciptakan merek (brand). Alhasil, tujuan IMC adalah bermaksud menciptakan kesetiaan pelanggan kepada merek (brand loyality). Dalam IMC, pelanggan memang diperlakukan sebagai teman atau partner (Duncan, 2002 : 8-9). Selanjutnya, jika terjadi hubungan yang berkepanjangan antara pemasar dan pelanggan/ khalayak sasaran, maka yang menjadi target dalam IMC adalah memperkuat nilai merek (brand equity) di hadapan para pelanggan, bukan untuk mendapat keuntungan semata-mata (Duncan, 2002: 19-21).

Perihal merek ini, dunia pemasaran memang sangat memperhitungkannya. Seperti halnya manusia yang memerlukan nama; begitu pula produk mesti punya nama (merek). Perusahaan atau lembaga juga selalu punya nama. Jika seseorang, produk, perusahaan, tak punya nama, maka sukar bagi orang untuk mengingatnya. Dengan punya nama atau merek, orang sudah bisa mengenalnya sebelum melihat produk/program tersebut. Bahkan untuk mencapai keberhasilan pemasaran, merek sama pentingnya dengan produk itu sendiri. Salah penamaan bisa fatal akibatnya. Sebaliknya, pemilihan nama (merek) yang baik akan merupakan sebuah kekuatan tersendiri (Stobart, 1994).

Merek/nama juga sangat penting untuk keperluan positioning produk/program di benak khalayak. Sekalipun merek bukan satu-satunya yang menyebabkan produk/program kita masuk ke dalam ingatan seseorang -faktor lain bisa karena kualitas, harga, bentuk, dan sebagainya - namun merek/nama diakui memiliki peran yang besar dalam memengaruhi diingatnya sebuah produk oleh khalayak. Padahal, positioning-usaha menempatkan produk kita ke dalam ingatan khalayak - amat diperlukan, mengingat daya ingat orang itu terbatas, agar produk kita dikenal dan diakses/diterima, sementara objek/informasi yang mesti diingat termasuk dari produk saingan amatlah banyaknya. Dengan nama yang baik, mungkin unik, diharapkan produk/program kita berhasil "mencuri" perhatian khalayak dan menyimpannya di benak mereka (Trout, 1996: 111-136).

Karena itu, seperti halnya dalam komunikasi pemasaran, dalam komunikasi pemasaran politik juga diperlukan desain produk politik, baik menyangkut kelembagaan, kepemimpinan, keanggotaan, kebijakan, dan kegiatan dari partai politik. Partai juga mesti memilih merek (brand) sebagai partai elit atau populis; konservatif atau liberalis; tradisionalis atau reformis; kanan atau kiri; nasionalis atau sekretarian; partai kader atau partai massa; dsb. Yang jelas, brand apa pun yang dipilih akan mempengaruhi citra (image) politik dan selanjutnya akan mempengaruhi opini publik dan dukungan politik kepadanya.

Juga, seperti halnya dalam komunikasi pemasaran, untuk menciptakan hubungan jangka panjang dengan konstituen, maka dalam pemasaran politik dengan IMC diperlukan komunikasi pemasaran secara terpadu (Lihat kembali Box 4). Sebelum peluncuran (launching), sang aktor perlu mempertimbangkan dengan matang platform politik dan menuangkannya ke dalam nama dan lambang politik serta memilih jati diri melalui perumusan visi dan misi politik. Kemudian, sang aktor melakukan berbagai kegiatan pemasaran politik, seperti periklanan politik, pertemuan dengan tokoh, membuat acara-acara khusus (special event) seperti seminar dan pawai politik, dan pertemuan umum/kampanye guna mendapatkan dukungan politik. Untuk memantapkan political loyality dan political equity sang aktor sebaiknya memelihara komunikasi politik dengan para konstituennya.

Dari uraian di atas, tampak bahwa pemasaran politik dengan bauran promosi atau IMC lebih dari sekadar dari pemanfaatkan berbagai saluran komunikasi politik untuk memengaruhi khalayak 
politik. Penggunaan ragam media dalam pemasaran politik seperti halnya dalam komunikasi pemasaran tiada adalah untuk menopang 4 (empat) fungsi pemasaran -DRIP (Fill, 1999: 3)- dari lembaga, pejabat atau kandidat politik:

- Differentiate product and service (membuat beda sebuah produk/jasa dari produk/jasa lain. Untuk komunikasi pemasaran politik berarti membuat produk politik dari produk politik saingan)

- Remind and reassure customer and potential customers (mengingatkan dan memperkuat kembali ingatan (calon) pelanggan mengenai produk/jasa yang ditawarkan. Dalam politik berarti mengingatkan khalayak politik mengenai produk politik yang sudah diumumkan)

- Inform (menginformasikan features produk/jasa yang ditawarkan; dalam konteks politik berarti karakter dan track record dari produk politik politik yang disampaikan kepada publik).

- Persuade targets to think or act in a particular way (meyakinkan target pasar untuk berpikir dan bertindak dalam satu cara tertentu terutama dalam bentuk pembelian produk/jasa yang ditawarkan. Dalam politik, berarti meyakinkan calon khalayak politik untuk berpikir dan bertindak dalam satu cara tertentu, terutama dalam bentuk pemberian dukungan kepada produk politik yang telah diumumkan).

Dalam situasi khalayak pasar politik sekarang, termasuk di Indonesia, yang semakin tersegmetasi bahkan terfragmentasi, terutama atas dasar kewilayahan dan aliran/ideologi politik, jelaslah peranan media dalam bauran promosi dan atau IMC politik sangat penting untuk melaksanakan DRIP setiap produk politik di tengah khalayak politik. Tanpa bantuan media, amatlah sukar tampaknya bagi komunikator politik menjangkau ragam khalayak politik yang luas secara geografis dan heterogen secara demografis dan psikografis dalam waktu yang singkat dan cepat.

\section{Proses dan Tahapan Komunikasi Pemasaran Politik}

Berbeda dari komunikasi pemasaran produk konsumtif(cunsumer product) yang lebi mewakili produk itu sendiri, komunikasi pemasaran politik bukan hanya untuk menjual produk politik itu sendiri, melainkan juga berkaitan erat dengan lembaga atau aktor politik dari mana produk politik itu dihasilkan. Oleh karena itu sangatlah tepat jika komunikasi pemasaran produk politik mengikuti

\section{Penampang 1. Perencanaan Komunikasi Strategis}

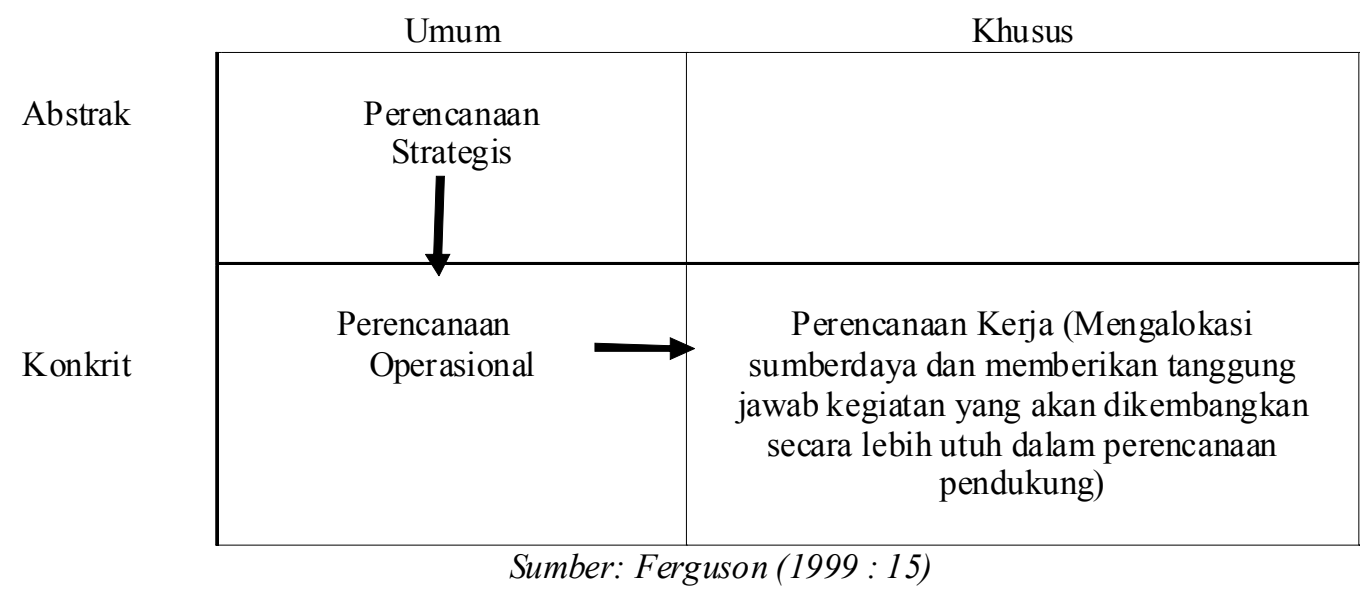




\section{Penampang 2: Proses Pemasaran untuk POP, SOP dan MOP}

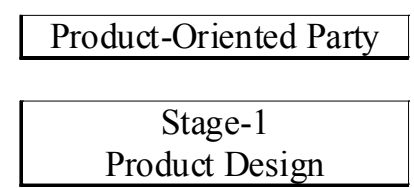

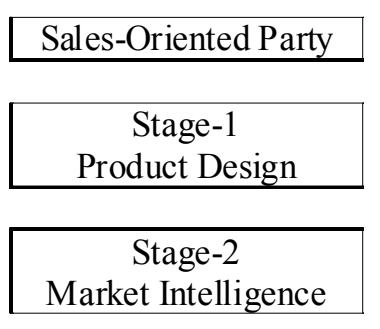

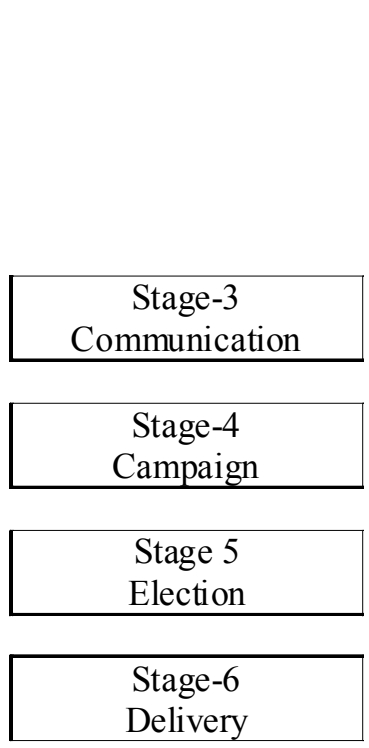

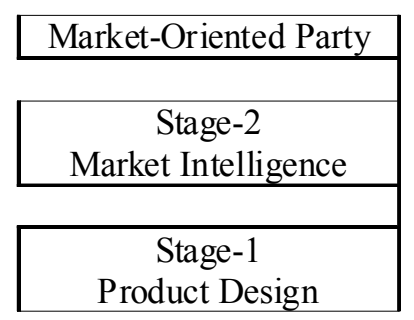

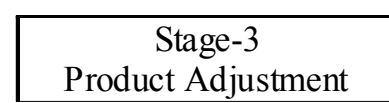

Stage-4

Implementation
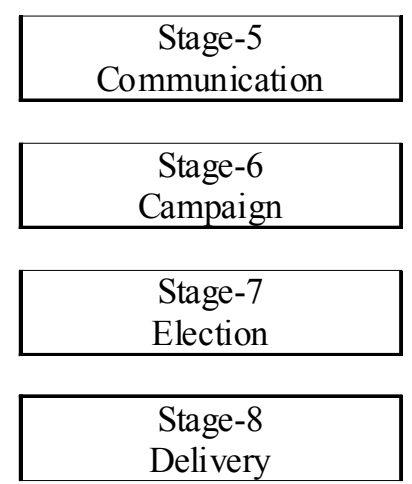

Sumber: Lilleker dan Lees-Marshment, 2005 : 6-11

proses yang berlaku dalam komunikasi strategis (Hamad dalam Jurnal Bisnis dan Birokrasi, 2006). Sehubungan dengan ini, komunikasi pemasaran politik bukan sekadar menjual produk politik itu sendiri, melainkan juga untuk menjual visi dan misi strategis lembaga atau aktor politik. Seperti tampak dalam Penampang 1, komunikasi pemasaran politik harus mencerminkan turunan (derivasi) dari perencanaan strategis lembaga politik (Ferguson, 1999: 11-17). Atas dasar itulah disusun perencanaan operasional dan perencanaan kerja komunikasi pemasaran politik.

Pada perencanaan strategis (strategic communication plan), pimpinan puncak menetapkan garis besar komunikasi pemasaran politik yang mencakup latar belakang, visi, misi, dan target komunikasi pemasaran politik; lingkungan eksternal dan internal organisasi; peluang dan tantangan; tema dan pesan; prioritas komunikasi; kerjasama dan negosiasi; indikator kinerja; dan antipasi sumber keuangan. Pada level ini, para elit politik menunjukkan arah dan corak komunikasi pemasaran politik yang akan dilakukan kepada para perencana operasional dan pelaksana teknis pemasaran politik.

Sebagai turunan dari perencanaan strategis, dalam perencanaan operasional pemasar politik menyusun urutan prioritas komunikasi; 
menegaskan keterkaitan antara tujuan komunikasi pemasaran politik dan rencana strategis institusi politik; melakukan identifikasi khalayak politik; menunjukkan kegiatan dan pelayanan yang bersifat mendukung; dan menentukan berapa banyak dana politik yang dianggarkan di antara prioritasprioritas yang ada.

Sedangkan dalam perencanaan kerja, pemasar politik membuat rencana kerja secara lebih konkret dan khusus. Dalam level ini, pemasar politik mengidentifikasi ide politik yang akan disampaikan kepada khalayak; mendesain pesan; menentukan indikator kinerja; menetapkan rencana-penerapan (milestones); menyusun metodologi evaluasi; dan mengalokasikan sumberdaya untuk setiap kegiatan pemasaran politik.

Agar pelaksanaannya berjalan secara terkontrol, komunikasi strategis biasanya melampaui empat tahapan: pra-desain, desain, eksekusi, dan monev (monitoring dan evaluasi). Demikian pula sebaiknya yang dilakukan dalam pemasaran politik dengan prinsip komunikasi strategis (Hamad, dalam Jurnal Bisnis dan Birokrasi, 2006). Dalam tahap pra-desain, pemasar politik melaksanakan analisis pasar dan melakukan STP lembaga politik dan menganalisis political behavior konstituen. Dalam tahap desain, pemasar politik mendesain produk politik dan merancang promotion mix of political atau IMC of political berikut alokasi sumberdayanya. Sedangkan pada tahap eksekusi, pemasar politik melaksanakan semua kegiatan yang telah dirancang pada tahap desain. Akhirnya, dengan metode yang dapat dipertanggung-jawabkan, pemasar politik melakukan penilaian kinerja pada tahap monev.

Namun, harus diakui, dalam pelaksanaannya tak semua pelaku politik melaksanakan komunikasi strategis seperti itu. Untuk pemasaran partai politik misalnya, Lees-Marshment (Lilleker dan LeesMarshment, 2005:6-11) menunjukkan tiga pendekatan yang berbeda: pendekatan POP (product-oriented party), SOP (sales-oriented party) dan MOP (marketing-oriented party). Perbedaan ketiganya dapat dilihat dalam Penampang 2.

Pendekatan POP, adalah pendekatan klasik, lebih banyak mengutamakan argumentasi, kepercayaan, nilai, norma yang diusung oleh suatu partai. Apa yang diharapkan adalah lahirnya rasa percaya, yakin, suka dari para pemilih atau khalayak terhadap partai politik tersebut, sehingga mereka tergerak untuk memilihnya. Partai yang menggunakan metode ini cenderung tidak bisa fleksibel dalam mengubah pandangan, ide, atau berbagai kebijakannya, meskipun jika partai tersebut gagal dalam pemilihan umum atau gagal mendapat dukungan dari para khalayaknya.

Pendekatan POP terdiri dari lima tahapan proses pemasaran. Pertama, product design, yaitu tahap dimana partai membuat produknya (seperti lambang, nama, visi, misi, jati diri, elit, massa, kegiatan, dsb) sesuai dengan kepercayaan, nilai atau norma dari para anggota dan pemimpinnya. Kedua, communication yaitu tahap merumuskan kampanye partai baik untuk jangka pendek, panjang bahkan sepanjang waktu untuk menyampaikan berbagai argumen partai kepada para pemilih. Ketiga, adalah tahap melaksanakan kampanye sesuai jadwal dalam rangka menyongsong pemilihan. Keempat, adalah jalannya proses pemilihan umum itu sendiri. Dan kelima, delivery yaitu tahap partai menyampaikan sekaligus menunjukkan bagaimana partai akan mewujudkan janji-janjinya di dalam pemerintahan.

Pendekatan SOP berupaya untuk mempersuasi khalayak melalui beragam kegiatan komunikasi pemasaran yang ekstensif. Hal ini termasuk pelaksanaan riset untuk periklanan dan penciptaan pesan. Pendekatan SOP berusaha untuk membuat khalayak ingin apa yang ditawarkan partai politik.

Pendekatan SOP lebih fokus ketimbang POP dan MOP dalam menjual produk partai. Setelah mendesain produk partai sesuai kepercayaan partai, langkah kedua adalah melakukan riset pasar untuk mengetahui seperti apa tanggapan khalayak terhadap partai berdasarkan segmen serta pendekatan komunikasi apa yang sebaiknya dipergunakan. Penelitain pasar (market intelligence) akan menginformasikan dua hal sekaligus mengenai komunikasi yang sedang berlangsung (tahap 3) dan tahapan kampanye yang resmi (tahap 4). Dengan demikian, marketing intellegence 
akan memastikan bahwa kampanye berjalan tertib, aktual, tersentralisasi, dan terpadu. Langkah ini dilakukan bukan hanya untuk memperkuat argumen tetapi juga untuk meyakinkan khalayak. Untuk mencapainya, digunakanlah beragam teknik penjualan dan komunikasi pemasaran melalui beragam media seperti surat, leaflet, poster, directmail videos, dan sebagainya. Pelaksanaan SOP yang tepat menjamin kemenangan sebuah partai. Tahap kelima adalah saat pemungutan suar; dan tahap terakhir adalah penyampaian kebijakan dan tujuan mereka dalam pemerintahan.

Pendekatan MOP berpendapat bahwa untuk memenangkan pemilu, sebuah partai haruslah terlebih dahulu memahami dan mengutamakan apa yang diinginkan oleh publik, untuk kemudian menuangkannya ke dalam produk-produk politik. Pendekatan MOP tidak berupaya untuk mengubah apa yang ada di benak khalayak, tidak juga berupaya mengemas pesan dan produk-produk politik dengan menarik, tapi lebih kepada penciptaan dan penyampaian pesan dan produkproduk politik yang memang dikehendaki oleh para khalayak. Pendekatan MOP tidak berangkat dari ideologi atau kepercayaan partai, tapi merupakan suatu langkah untuk mengembangkan, menciptakan dan menyampaikan rangkaian kebijakan politik yang realistis memenuhi kebutuhan khalayak dan pasarnya. Seluruh sumber daya dari sebuah lembaga politik digunakan sepenuhnya untuk merumuskan dan menyampaikan rangkaian produk politik yang menjawab kebutuhan khalayak.

Karena itulah pendekatan MOP dimulai dengan tahap marketing intelligence, yang bertujuan untuk mengetahui pola perilaku khalayak, keinginan, kebutuhan, dan prioritas dari para khalayak melalui beragam metode pengumpulan data (polling, focus groups, konsultasi publik dan pertemuan). Tahap kedua adalah mendesain produk partai berdasarkan data marketing intelligence tersebut. Pada tahap selanjutnya (tahap product adjustment), penyesuaian produk mungkin saja terjadi karena empat faktor yaitu achievability, internal reaction, competition analysis, and support analysis.
Achievability: sebuah partai hendaknya tidak menjanjikan sesuatu yang sulit atau direalisasikan dalam pemerintahan. Internal Reaction: analisis sekaligus penyesuaian antara tanggapan atau tuntutan dari khalayak dengan tanggapan yang diberikan semua anggota partai. Competition Analysis: menganalisis kekuatan dan kelemahan partai saingan. Support Analysis: pengenalan sekaligus analisis terhadap beragam pihak yang memegang peran penting dalam merealisasikan produk politik.

Dalam tahap keempat implementasi dilakukan penyatuan pendapat di antara pihak internal partai mengenai produk politik yang hendak disampaikan ke khalayak. Produk inilah yang akan akan dikomunikasikan kepada khalayak pada tahap kelima. Pada tahap ini terjadi interaksi antara pihak internal dan eksternal partai secara berkesinambungan.

Tahap kampanye pemilu adalah momentum penguatan aspek-aspek produk politik yang penting terhadap khalayak, supaya khalayak tetap yakin bahwa partai dan produk politik merupakan jawaban yang tepat dari kebutuhan mereka. Tahap ketujuh adalah pemilihan; dan jika produk partai tersebut dikomunikasikan dengan baik maka partai itu akan terpilih dalam pemilu.

Tahap terakhir, deliver adalah tahap penyampaian atau aktualisasi produk politik tersebut dalam pemerintahan. Tugas sulit ini merupakan hal krusial untuk menjamin bahwa para pemilih merasa puas dan yakin terhadap lembaga tersebut. Oleh karenanya, lembaga harus tetap melakukan marketing inteligence dan menyesuaikan produk-produknya terhadap perkembangan yang ada.

Dari uraian di atas tampak bahwa ketiga pendekatan pemasaran partai tersebut pada dasarnya menggunakan prinsip-prinsip manajemen komunikasi strategis. Bahwasanya rencana dan kegiatan komunikasi pemasaran politik merupakan terjemahan dari platform partai; dan secara umum aktivitas komunikasi pemasaran politik dalam ketiga pendekatan ini mengkuti tiga tahapan perencanaan: strategis (pada tahap desain produk politik), operasional (pada tahap 
komunikasi), dan rencana kerja (tahap kampanye). Pertanyaannya dimanakah letak kegiatan komunikasi pemasaran politiknya itu sendiri dalam tahapan komunikasi pemasaran politik ini? Dan, kapankah digunakan ragam jenis media untuk kegiatan komunikasi pemasaran politik ini? Jika dilihat dari perspektif IMC, maka komunikasi pemasaran politik sesungguhnya sudah dimulai sejak desain produk politik hingga ke tahap paling akhir (delivery), baik pada POP, SOP, maupun MOP. Jika hanya menggunakan bauran promosi politik, maka pelaksanaanya pada tahap kampanye saja kegiatan komunikasi pemasaran politik itu dilaksanakan. Pilihan mana saja yang ditempuh, di dalamnya dapat digunakan beragam media komunikasi pemasaran politik (ATL, BTL, event, media baru, komunikasi interpesonal, media tradisional) baik secara parsial maupun secara integratif tergantung pendekatan komunikasi pemasaran yang kita pilih.

\section{Melihat Praktik \\ Komunikasi Pemasaran Politik}

Di Indonesia, praktik komunikasi pemasaran politik dimulai sejak Pemilu 1999. Salah satu bentuknya adalah periklanan politik dengan belanja iklan terbesar diduduki Golkar (Rp. 7,640 milyar) disusul oleh PDIP (Rp 5,792.milyar), Partai Republik (Rp 2,970 milyar), PKB(Rp. 2,340 milyar), PKP (Rp 1,354 milyar), Partai Daulat Rakyat (Rp. 985,510 juta), PPP (Rp 506,540 juta) dan PBB sebesar Rp. 413,350 juta (Cakram No. 185, Juli 1999, hal. 19)

Periklanan politik juga banyak dipilih dalam Pemilu 2004 dan Pilpers. PDIP yang paling banyak mengeluarkan dana iklan, yaitu sekitar Rp. 39,258 miliar. Selanjutnya, diikuti Partai Golkar (Rp. 21,725 miliar), Partai Karya Peduli Bangsa (Rp. 6,858 miliar), Partai Amanat Nasional (Rp. 6,854 miliar), Partai Demokrat (Rp. 6,257 miliar). Dalam daftar sepuluh besar parpol terbesar mengeluarkan dana iklan di media juga memasukkan Partai Persatuan Pembangunan, PK Sejahtera, PKB, Partai Bintang Reformasi dan Partai Persatuan Daerah. Di urutan bawah belanja iklan parpol di media mencatat,
Partai Buruh Sosial Demokrat (Rp. 76,06 juta), Partai PNUI(Rp. 158,48 juta), Partai Pelopor (Rp. 169,995 miliar) dan Partai Merdeka (Rp. 206,92 miliar). Televisi adalah media yang paling banyak menelan dana iklan parpol, yaitu sekitar Rp. 75,434 miliar. Selanjutnya diikuti media cetak (Rp. 35,184 miliar) dan radio (Rp. 2,163 miliar). (Tempo Interaktif, Minggu, 09 Mei 2004 | 21:27 WIB).

Sedangkan untuk Capres, dari seluruh biaya iklan TV kampanye capres sebesar Rp 32,774 miliar, sejak 31 Mei sampai 12 Juni, tim sukses WirantoSalahuddin Wahid mengeluarkan dana paling tinggi, yaitu sebesar Rp 10,149 miliar. Sementara, pasangan Amien Rais-Siswono Yudo Husodo mengeluarkan biaya terkecil, yaitu Rp 2,091 miliar. (Tempo Interaktif, Kamis, 24 Juni 2004| 14:52 WIB).

Di Barat, negara AS sudah lama mempraktikkan pemasaran politik, terutama dalam bentuk periklanan politik, yaitu sejak 1952 dalam bentuk iklan politik di televisi. Lyndon B Johnson tahun pada 1964 membuat iklan politik bertajuk "Bunga Daisy”. Karena kontroversial, iklan politik itu hanya ditayangkan sekali pada 7 September 1964, di televisi CBS. Dalam kampanye Pemilu 1988, tiap calon presiden AS mengeluarkan dana ratarata 228 juta dollar AS untuk belanja iklan politik. Jumlah ini sekitar 8,4 persen dari biaya kampanye keseluruhan.

Setelah itu, biaya iklan politik di AS selalu meroket. Pada Pemilu 1992, calon presiden Bush dan Clinton sama-sama membelanjakan 60 persen anggaran kampanye untuk iklan radio dan televisi. Pada Pemilu 2000, calon presiden George W Bush (Partai Republik) mengeluarkan biaya iklan 47,3 juta dollar. Al Gore (Partai Demokrat) menghabiskan 47,6 juta dollar (Kompas, 15 Maret 2004). Dan kampanye presiden AS 2004 mungkin yang termahal sepanjang sejarah negara itu. Baik Bush maupun Kerry mengucurkan dana seperti tanpa batas. Kedua tim sukses telah mengeluarkan dana lebih dari US\$ 400 juta atau 4 trilyun rupiah (Swa.co.id. 26 Oktober 2004).

Yang memperihatinkan adalah penyalahgunaan komunikasi pemasaran politik dari yang seharusnya mempersuasi publik menjadi propaganda politik. Memang ada perbedaan yang jelas 
antara persuasi dan propaganda dalam komunikasi politik (Johnson-Cartee dan Copeland, 2004). Persuasi adalah usaha mempengaruhi persepsi dan kesan orang dengan mengeksplorasi perasaan, kepribadian, kerangka pikir, dan sebagainya. Persuasi membuka peluang adanya dialog dan negosisasi antara komunikator dan penerima. Karenanya penggunaan saluran interpersonal dianggap lebih efektif daripada media massa karena persuasi memerlukan penyesuaian dan feedback dari penerima. Sedangkan propaganda adalah upaya mempengaruhi orang lain secara searah dengan memanfaatkan sentimen norma kelompok, sehingga, pemakaian media massa dinilai lebih efektif karena dalam propaganda pesan disusun secara akurat, intensif, dan berdasarkan analisis yang lengkap terhadap norma kelompok.

Sementara itu, seperti sudah disinggung di atas, pemasaran politik dewasa ini baik dengan bauran promosi maupun dengan IMC, cenderung memakai media massa, sehingga teknik propaganda sangat berpeluang masuk ke dalam pemasaran politik. Ini disebabkan karena pemasaran politik juga memperhitungkan norma kelompok dan sangat media-oriented seperti halnya dalam propaganda. Apalagi di Indonesia yang masyarakatnya masih kental dengan primordialisme, guyub, dan partnerilistik. Dalam kondisi seperti itu, terbuka kemungkinan dilakukannya propaganda 5B: black campaign (menjelek-jelekkan pihak lain), blame campaign (menyalahkan pihak lain), blank campaign (mengumbar janji kosong), blocking campaign (mempertahankan opini diri sendiri) dan backing campaign (menggunakan orang tertentu untuk membela diri) seraya memanfaatkan media dengan seluas-luasnya.

Kenyatannya, dari hasil pengamatan terhadap komunikasi pemasaran politik selama pemilu 1999 dan 2004, pilpres 2004, dan pilkada di berbagai tempat, ada kecenderungan para aktor dan partai politik menggunakan salah satu dari lima jenis kampaye ini. Dalam kampanye pilpres 2004, misalnya, sekelompok orang melakukan black camaign terhadap capres Wiranto dengan cara menerbitkan buku yang menuding Wiranto terlibat dalam masalah pamswakarsa pada Sidang Istimewa MPR 1999. Kubu Megawati selaku incumbent acapkali menggunakan blocking campaign atas prestasi yang telah dicapainya. Sedangkan pasangan SBY-JK banyak menggunakan backing campaign melalui pelibatan lembaga survey untuk membela dan mendongkrak popularitas diri sendiri. Boleh dibilang, pasangan Hamzah Haz dan Agum Gumelar terlalu banyak blank campaign, mengumbar janji kosong ketika itu. Sementara, Amien Rais sejak awal keterlibatanya dalam politik banyak memakai blame campaign terutama terhadap Orba khususnya lagi Soeharto.

Tak jauh beda hal itu terjadi pula dalam pilkada. Sejumlah kandidat dalam pilkada terkesan berlebihan dalam menggunakan media; seperti dilakukan Bupati Indramayu Jawa Barat dan Wakil Bupati Purwakarta Jawa Barat, yang sengaja menggunakan Kitab Suci Al-Quran sebagai media kampanye. Mereka menempelkan foto wajah dan pesan politik mereka di dalam kitab suci tersebut. Para incumbent, baik bupati, walikota, atau gubernur yang mau maju lagi mencuri start pemasaran politik. Mereka menggunakan bermacam media terutama lini bawah seperti sticker, spanduk, selebaran, almanak, dan sebagainya, untuk menarik perhatian masyarakat.

Penyalahgunaan pemasaran politik ini juga terjadi di AS. Diberitakan, dua iklan Bush berisi pernyataan-pernyataan yang menyesatkan tapi tetap disiarkan di 45 kota dengan mengambil 9.000 slot iklan. Iklan-iklan berisi fakta yang dibelokkan itu menuduh Kerry mendukung kenaikan pajak bahan bakar dan pajak terhadap keluarga kelas menengah. Padahal, menurut Annenberg Political Fact Check, lembaga pemantau kesahihan pernyataan-pernyataan politik, klaim itu tidak benar. Disebutkan oleh lembaga yang memantau iklan televisi di 100 pasar iklan tertinggi itu, ada dua seri iklan dari pihak Bush yang kedapatan berisi fakta keliru, versi "Thinking Mom" dengan biaya US\$ 2,5 juta dan “Clockwork” seharga US\$ 5,4 juta. Tercatat delapan juta dolar yang keluar untuk iklaniklan menyimpang itu. (Swa.co.id. 26 Oktober 2004).

Itulah sebabnya dalam kegiatan komunikasi 
pemasaran politik perlu dipertimbangkan aspek etika dan legalnya. Jika tidak, khalayak politik bisa menjadi takut, sedih, dan kecewa karena dijejali dengan informasi bohong, pesan politik yang mengesankan keinginan benar dan menang sendiri, serta sikap saling menyalahkan dari para aktor atau lembaga politik (Dentron dalam Dentron, 2000 : 241246). Pemasaran politik yang tak beretika hanya akan menghancurkan civil society yang justru semestinya menjadi dasar dan tujuan sistem demokrasi dimana hanya dalam sistem itu komunikasi pemasaran politik dipraktikkan secara bebas.

\section{Kesimpulan}

Komunikasi pemasaran politik bukan hanya bersifat pengayaan terhadap komunikasi politik secara konseptual, melainkan menjadi bagian yang lebih praktis dari komunikasi politik. Kini, komunikasi pemasaran politik telah dipraktikkan di negara-negara yang menerapkan sistem demokrasi ala pasar bebas termasuk Indonesia.

Bersamaan dengan perkembangan prinsip dan metode komunikasi pemasaran, praktik komunikasi pemasaran politik juga sudah mengarah pada penerapan integrated marketing communication (IMC). Upaya membangun hubungan dengan konstituen sudah dilakukan sejak desain produk politik dengan dukungan riset pemasaran politik. Seperti halnya dalam dunia pemasaran, kini semakin besar kesadaran untuk memahami karakter dan prilaku khalayak sebelum para pelaku politik berbicara politik atau memasarkan produk politiknya kepada kontituen.

Sejalan dengan perkembangan industri media, komunikasi pemasaran politik kini dapat dilaksanakan secara lebih mudah, ekstensif, dan intensif. Tapi, justru karena itulah, para pelaku politik bisa mudah tergoda untuk melakukan propaganda politik ketimbang mempersuasi konstituen melalui kegiatan komunikasi pemasaran politik. Untuk menghindari penyalahgunaan ini, diperlukan etika komukasi politik umumnya dan etika komunikasi pemasaran politik khususnya.

\section{Daftar Pustaka}

Axford, Barrie dan Richard Huggins. 2001. New Media and Politics, London-Thousand OaksNew Delhi: Sage Publication.

Dentron Jr, Robert E (ed). 2000. Political Communication Ethics, An Oxymoron? Westport, Connecticut, London: Praeger.

Duncan, Tom. 2002. IMC Using Advertising and Promotion to Build Brands, Boston: McGraw-Hill Irwin.

Ferguson, Sherry Devereaux. 1999. Communications Planning, An Integrated Approach, London: Sage Publication.

Fill, Chris. 1999. Marketing Communications Contexts, Contents and Strategies, London-New York: Prentice Hall.

Johson-Cartee, Karen S dan Gary A. Copeland. 2004. Strategic Political Communication Rethingking Social Influence, Persuasion and Propaganda, Lanham-Bolulder-New York-Toronto-Oxford: Rowman and Littlefield.

Lange, Bernd-Peter dan David Ward (ed). 2004. The Media and Elections A Handbook and Comparative Study, Mahwah,New Jersey London: Lawrence Erlbaum Associates.

Lilleker, Darren G, dan Jennifer Lees-Mashment (ed). 2005. Political Marketing, A Comparative Perspective, Manchester University Press.

McNair, Brian. 2003. An Introduction to Political Communication, London: Routledge.

Newman, Bruce I, (editor). 1999. Handbook of Political Marketing, Thousand Oaks, California : Sage Publication.

Nimmo, Dan. 1978. Political Communication and Public Opinion in America, Santa Monica, California : Goodyear Publishing. 
O'Shaughnessy, Nicholas J dan Stephan C. M. Hanneberg (ed). 2002. The Idea of Political Marketing Westport, Connecticut, London: Praeger.

Stobart, Paul (eds), 1994. Brand Power, London: MacMillan.

Schultz, Don E, Stanley I. Tannenbaum, dan Robert F. Lauterborn, 1994. Integrated Marketing Communication, Illinois: NTC Business Books.

Sutisna, 2002. Perilaku Konsumen dan KomunikasiPemasaran. Bandung: PT Remaja Rosda Karya.
Trout, Jack, 1996. The New Positioning, New York: McGraw Hill.

Cakram, Majalah Periklanan, Promosi dan Kehumasan No. 185, Juli 1999.

Jurnal Bisnis dan Birokrasi, Departemen Ilmu Administrasi FISIP UI, 2006.

Kompas, 15 Maret 2004.

Swa.co.id, 26 Oktober 2004.

Tempo Interaktif, Minggu, 09 Mei 2004 | 21:27 WIB. 